\title{
Epidemio-therapeutic Survey on Malnourished Children Aged 0-5 Years Old in the Gbado-Lite Health Zone (Nord Ubangi Province, Democratic Republic of the Congo)
}

\author{
Koto-te-Nyiwa Ngbolua ${ }^{1,2,3, *}$, Guy Kumbali Ngambika², Blaise Mbembo-wa-Mbembo ${ }^{1}$, \\ Ruphin Djolu Djoza ${ }^{2}$, Gédéon Ngiala Bongo ${ }^{1,2}$, Falanga Mawi Clarisse ${ }^{1}$, Benjamin Gbolo \\ $\underline{\text { Zoawe }}^{1,2}$, Masengo Ashande Colette ${ }^{2}$, Libwa Momi Tabonge Bertin 3 \\ ${ }^{1}$ Department of Biology, Faculty of Science, University of Kinshasa, Kinshasa, \\ Democratic Republic of the Congo \\ ${ }^{2}$ Faculty of Medicine, University of Gbado-Lite, Gbado-Lite, Nord Ubangi, \\ Democratic Republic of the Congo \\ ${ }^{3}$ Faculty of Agricultural Sciences, University Of Gbado-Lite, Gbado-Lite, Nord Ubangi, \\ Democratic Republic of the Congo \\ Corresponding author: Prof. Koto-te-Nyiwa Ngbolua (PhD) \\ Email: jpngbolua@unikin.ac.cd
}

\begin{abstract}
:
Child malnutrition is one cause of death worldwide, but the greatest burden is borne by African countries, particularly in Sub-Saharan Africa. The Democratic Republic of Congo, despite its wealth of biodiversity, is confronted with this phenomenon which seriously hinders its development. A cross-sectional descriptive study was conducted in The Nord Ubangi Province from 01 to 31 December 2016 on a population of 133 malnourished children aged 0 to 5. The results show that the 2 to 3 year old age group (25-36 months) was the most affected by malnutrition. The most affected children were male, at 52.63\%. Most of these children, 24.8\%, resided in rural areas around Gbadolite. The majority of their parents, $61.6 \%$, was farmers or only engaged in housework. $78.9 \%$ of respondents had edema in their bodies, and $91.7 \%$ did not meet the appetite test. These children were subjected to antibacterial treatment outside of ready-to-use therapeutic foods (ATPE). After this treatment, the cure rate was satisfactory at $73.6 \%$.

Keywords :

health public; child malnutrition; child morbidity; Nord-Ubangi; Democratic Republic of the Congo.
\end{abstract}

\section{Introduction}

Nowadays, malnutrition remains a major public health problem, particularly in developing countries. In all its forms, malnutrition hinders the child's physical and mental development, decreases resistance to disease, increases the risk of early death and leads to poor academic performance later in life $[1,2]$. Malnutrition can have a variety of forms working synergistically such as protein-energy malnutrition and micronutrient deficiency disorders [2]. According to UNICEF, nearly 12 million deaths occur each year in the developing world among children under five, $55 \%$ can be attributed directly or indirectly to malnutrition [2].

In the Democratic Republic of the Congo (DRC), UNICEF estimates that 6 million of children under five years old are chronically malnourished or stunted while 1.9 million children who suffer from severe acute malnutrition and 1.5 million suffer from moderate acute malnutrition [3]. According to the Demographic and Health Survey (EDS) 2013-2014, 8\% of children under the age of five are acutely malnourished (3\% in severe form) and $43 \%$ are chronically malnourished [4]. The same survey reported that in DRC, the prevalence of acute malnutrition exceeds the critical threshold of $10 \%$ in several provinces.

The province of Nord Ubangi is heavily affected by child malnutrition; however, no studies have so far been initiated to assess the impact of this scourge on the population lifestyle in this 
part of the DRC. Henceforth, the main aim of the current research work was to assess the prevalence of malnutrition among children aged between 0 to 5 years in Gbado-Lite city. The findings of this study can help to define the need to establish a care center in order to improve the strategy in the fight against malnutrition.

\section{Metodology}

This study has a cross-sectional and descriptive design. It was carried out in Gbado-Lite city in Nord Ubangi, DRC between January $1^{\text {st }}$ and December $31^{\text {st }}$, 2016. The sample size was of 133 cases of malnourished children under five in General Hospital of Reference of Gbado-Lite city.

The following parameters were selected: socio-demographic parameters (Patient age in month; Sex; location, Parent's profession), brachial perimeter; Edema; Appetite test; Signs at admission; treatment and release form. All data were computed and analyzed using Graph pad version 6 whereby descriptive statistics (frequency, percentage) were considered.

For ethical reasons, the aim of the research was presented to the participants who were to assess the prevalence of malnutrition among children aged fewer than five in Gbado-Lite city. It was crucial to request the informed consent of participants and inform them about the guarantee of confidentiality of the answers provided.

In order to facilitate the participation, the interviews were held in appropriate facilities and the consent was read to the respondent prior to the interview.

\section{Discussion}

\subsection{Socio-demographic characteristics}

The table 1 gives the socio-demographic characteristics of the children.

Table 1. Socio-demographic characteristics of malnourished children

\begin{tabular}{|c|c|c|}
\hline Variables & Frequency & Percentage $(\%)$ \\
\hline \multicolumn{3}{|l|}{ Sex } \\
\hline o Male & 70 & 53 \\
\hline$\circ$ Female & 63 & 47 \\
\hline \multicolumn{3}{|l|}{ Age (months) } \\
\hline ० 3-8 & 25 & 19 \\
\hline ○ 13-24 & 27 & 20 \\
\hline$\circ \quad 25-36$ & 36 & 27 \\
\hline ○ $37-48$ & 27 & 20 \\
\hline$\circ \quad 49-60$ & 18 & 14 \\
\hline \multicolumn{3}{|l|}{ Place of residence } \\
\hline o Kaya & 24 & 18 \\
\hline o Mbanza & 30 & 23 \\
\hline$\circ$ Fondation & 5 & 4 \\
\hline ○ Taba & 10 & 8 \\
\hline$\circ$ Camp Mbinza & 4 & 3 \\
\hline ○ Buse & 4 & 3 \\
\hline O En dehors & 33 & 25 \\
\hline O Camp INKE & 9 & 6 \\
\hline$\circ$ Pangoma & 14 & 10 \\
\hline \multicolumn{3}{|l|}{ Parents' profession } \\
\hline$\circ$ Farmer/House & 82 & 62 \\
\hline
\end{tabular}




\begin{tabular}{llcc}
$\circ$ & Saleswoman & 28 & 21 \\
$\circ$ & Employee & 14 & 11 \\
$\circ$ & Military & 3 & 2 \\
$\circ$ & Refugee & 6 & 5 \\
\hline
\end{tabular}

This table shows that the age group of malnourished children between 25-36 months is the most affected followed by the 13-24 month age group. The bottom of the scale is occupied by children ranging in age from 49-60 months. These findings are different from Tano et al. [5] who reported that malnutrition preferentially affected children aged between 12 and 23 months [6] meanwhile Nguefack et al. [7] reported that the most affected age group was 12-23 months [7].

In this study, the average age of malnourished children was 27 months and this average is higher than that observed in several reports $[6-10,11]$. As to the gender of respondents, it was observed a predominance of male malnourished children (53\%), and these findings corroborate with Louis [12].

A survey conducted by the 2013-2014 ESD reported similar cases of male predominance compared to the female [4] while Nguefack et al. [7] reported the same findings. A study in Uganda also highlighted the dominance of male children (63\%) [11]. However, Musimwa [12] reported a predominance of malnourished female children (55.87\%) compared to male children (44.13\%). Regarding the place of residence, the largest number of malnourished children came from the area called "En dehors" (25\%) of the total workforce. These environments outside the city of Gbadolite act as rural areas in which habitats would not benefit from better sanitary and nutritional conditions, and would therefore be more exposed. Similar results are confirmed in several studies $[12,13]$. Concerning the profession of parents, it is observed that the majority of the parents surveyed $(62 \%)$, are farmers.

The predominance of agriculture leads farmers into a vulnerability that leads to the paradox that "the more farmers a country has, the hungrier it is" [14]. These results are similar to the reality of the province of Grand Equateur, where the poverty rate is among the highest in the country [15]. A number of studies have shown that child malnutrition is deeply rooted by poverty [16-18]. However, the relationship between poverty and child malnutrition is quite complex. The literature has shown that malnutrition affects not only poor households, but also non-poor households [1921]. High household incomes cannot guarantee a satisfactory nutritional outcome for children if households lack hygienic care, food quality and access to healthcare [22, 23].

\subsection{Clinical diagnosis}

\section{○ Appreciation on Edema}

The figure 1 shows the frequency of edema in malnourished children surveyed in Gbado-Lite city.

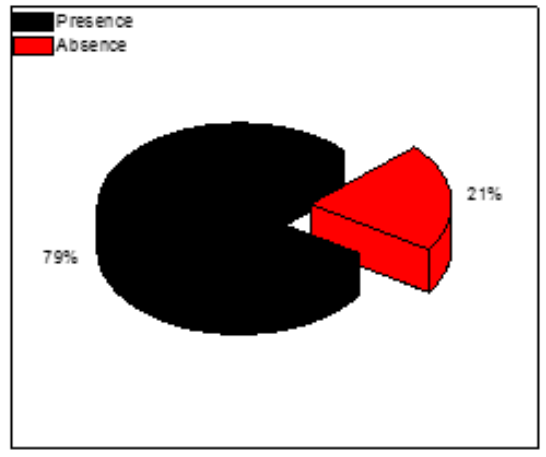

Figure 1. Appreciation on edema 
It is observed that in the majority of cases, children had edema in their bodies. Musimwa (2017) reported that $19.0 \%$ had presented edema [13]. Other studies have confirmed the presence of edema, most often bilateral, in malnourished children [11, 24, 25].

\section{○ Assessment on the appetite test}

An update on the appetite test is displayed in the figure 2 below.

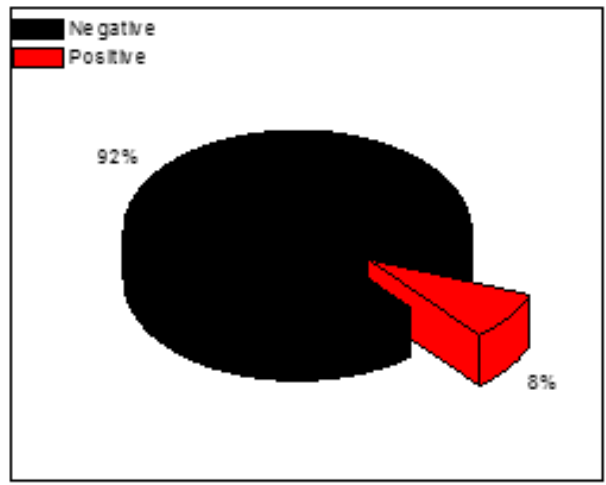

Figure 2. Assessment on the appetite test

From the above figure, it is observed that 122 children (92\%) did not pass the appetite test, while 11 children (8\%) were able to pass the appetite test. These results confirm a study published by WHO (2000), which found that the majority of malnourished children regularly suffer from a lack of appetite [26]. These results corroborate those found by Mukalay et al. (2010), which detected a high loss of appetite in malnourished children under the age of 5 [27].

\section{- Assessment on the treatment administered}

The figure 3 shows how children were treated outside of the additional treatment with ATPE (ready-to-use therapeutic foods).

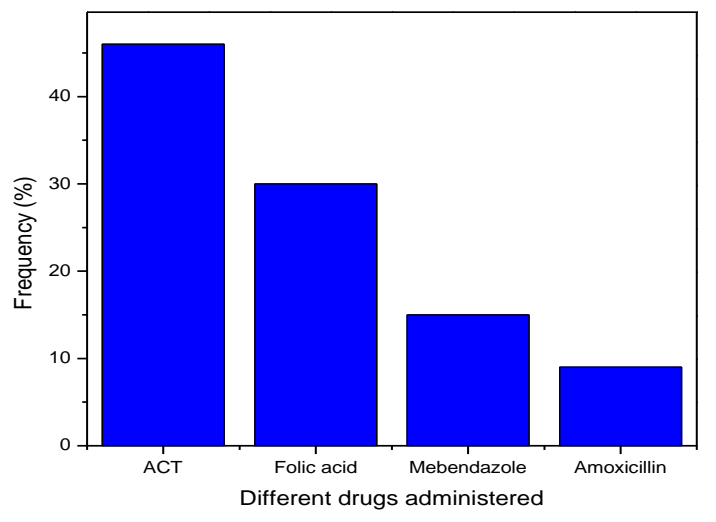

Figure 3. Frequency on the treatment administered

This table shows us that $46 \%$ of children were under the cover of ACT (Artemisinin Combined Therapy) followed by 40 cases or $30 \%$ who benefit from folic acid and 20 cases or 15\% who received mebendazole. Hospitalized children with severe acute malnutrition (SAM) are traditionally treated with empirical antibiotics as part of their routine management [28]. Several studies have confirmed this concern for serious bacterial infections in malnourished hospitalized 
children [25-27]. A study published in 2010 showed the efficacy of amoxicillin in antibacterial treatment in malnourished children [28].

\section{$\bigcirc \quad$ Releasing method}

The figure 4 traces the different releasing methods after they are taken care of.

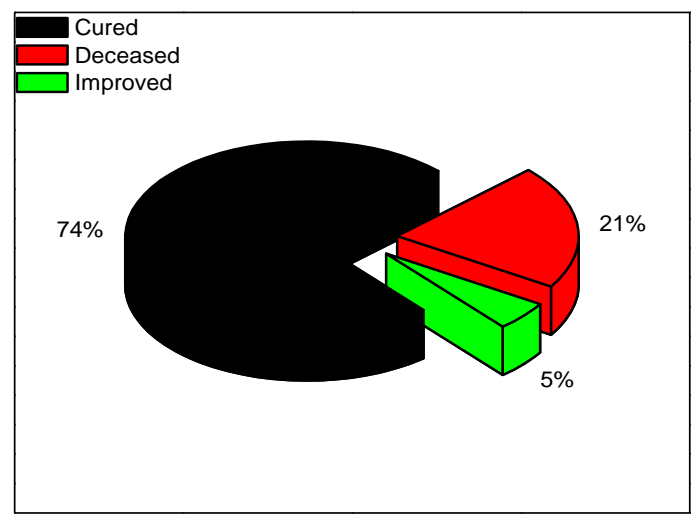

Figure 4. How the malnourished are released

The figure shows that 98 cases, $(74 \%)$ were cured before discharge, while 28 cases $(21 \%)$ had died compared to 7 cases $(5 \%)$ who had come out improved. We find that the cure rate for malnourished children is satisfactory in Nord Ubangi province, but it is still lower than that found by Kambale et al. [29]. The latter noticed a cure rate of $90.8 \%$ out of a total of 574 malnourished children. In 2007, a study in Malawi of 2131 severely malnourished children reported $89 \%$ of children cured and $85 \%$ of a total of 806 with moderate malnutrition [31]. On the other hand, the mortality rate reported in this study is much higher than that found by Bitwe et al. [30] in Nord Kivu province, 414 malnourished children were hospitalized at Goma Provincial Hospital. They reported a mortality rate of $15 \%$ for all of these children. Kambale et al. reported a much lower case fatality rate of $7.5 \%$ of a population of 574 malnourished children in Sud Kivu province [29].

\section{Conclusion}

The nutritional situation of children in the province of Nord-Ubangi in Democratic Republic of the Congo is precarious, despite the local wealth in terms of the availability of food. This shows that the fight against malnutrition is not based solely on the availability of food, education and medical treatment would improve the lives of such category of population.

\section{References}

[1]. Cheick ODC, 2014. Connaissances, attitudes et pratiques des mères ou gardiennes d'enfants malnutris face à la malnutrition des enfants de 6 à 59 mois vus en consultation au CSRéf de Niono en 2013. Thèse doctorat, Université des Sciences, des Techniques et des Technologies de Bamako, République du Mali.

[2]. Chang SM, Walker SP, Grantham-McGregor S, Powell CA, 2002. Early childhood stunting and later behaviour and school achievement. J Child Psychol Psychiatry; 43(6): 775-83.

[3]. UNICEF, 1998. La malnutrition: causes, conséquences et solutions.

[4]. UNICEF, 2017. Malnutrition en République démocratique du Congo.

[5]. EDS-RDC, 2013-2014. Enquête Démographique et de Santé. 
[6]. Tano OA, Tiembré I, Konan YE, Donnen P, Dagnan N'S, Koffi K, Diarra-Nama AJ, Dramaix M, 2010. Malnutrition chronique chez les enfants de moins de 5 ans au nord de la côte d'ivoire. Santé publique 22(2) :213-220.

[7]. Nguefack F, Adjahoung CA, Keugoung B, Kamgaing N, Dongmo R, 2015. Prise en charge hospitalière de la malnutrition aiguë sévère chez l'enfant avec des préparations locales alternatives aux F-75 et F-100: Résultats et défis. Pan African Medical Journal. doi:10.11604/pamj.2015.21.329.6632.

[8]. Louis W, 2012. La Malnutrition aiguë sévère et ses facteurs de risque chez les enfants allaités de moins de 36 mois au Sud Kivu, en RDC (ex Zaïre): Master Complémentaire en Santé Publique : Santé et Développement. Université libre de Bruxelles, Belgique.

[9]. Musimwa MA, 2017. Malnutrition chez l'enfant de moins de 5 ans à Lubumbashi et ses environs. Approche épidémio-clinique et biochimique dans un milieu minier. Thèse de doctorat, Université de Lubumbashi, République démocratique du Congo.

[10]. Sinnaeve O, Testa J, Ablefonlin E, Ayivi B, 2006. Aspects épidémiologiques de la malnutrition infanto-juvénile à Cotonou (Bénin). Médecine Tropicale 66(2): 177- 181.

[11]. Bachou H, Tylleskär T, Kaddu-Mulindwa HD, Tumwine KJ, 2006. Bacteraemia among severely malnourished children infected and uninfected with the human immunodeficiency virus-1 in Kampala, Uganda. BMC Infectious Diseases. 160(6):1471-2334.

[12]. Bucekuderhwa C, Mapatano S, 2013. Comprendre la dynamique de la vulnérabilité à l'insécurité alimentaire au Sud-Kivu. VertigO - La Revue électronique en Sciences de l'Environnement, http://journals.openedition.org/vertigo/13819.

[13]. PNUD, 2013. Pauvreté et conditions de vie des ménages, République démocratique du Congo.

[14]. Deolalikar AB, 2005. Poverty and child malnutrition in Bangladesh. J Develop Soc. 21(1-2): 55-90.

[15]. Thang NM, Popkin B, 2003. Child malnutrition in Vietnam and its transition in an era of economic growth. J Hum Nutr Diet. 16(4): 233-244.

[16]. Pongou R, Ezzati M, Salomon J, 2006. Household and community socioeconomic and environmental determinants of child nutritional status in Cameroon. BMC Public Health 6: 98. doi: 10.1186/1471-2458-6-98.

[17]. Chee HL, Khor GL, Fatimah A, Wan Manan WM, Mohd Nasir MT, Nik Shanita S, Norimah AK, Norlela MH, Normah H, Poh BK, Rokiah MY, 2002. Nutritional assessment of preschool children in rural villages of the family dynamics, lifestyles and nutrition study (19972001). II. Prevalence of under nutrition and relationship to household socio-economic indicators. Malays J Nutr. 8(1):33-53.

[18]. Zamaliah MM, Khor GL, Tee ES, 2002. Socio-economic determinants of nutritional status of children in rural Peninsular Malaysia. Asia Pac J Clin Nutr. 7 (3/4): 307-310.

[19]. Mukuku O, Mutombo MA, Kamona KL, Lubala KT, Mawaw MP, Aloni NM, Wembonyama OS, Luboya NO, 2018. Développement d'un score prédictif de malnutrition aiguë sévère chez les enfants de moins de 5 ans. Pan Afr Med J. 29: 185. doi:10.11604/pamj.2018.29.185.13713.

[20]. Agee MD, 2010. Reducing child malnutrition in Nigeria: combined effects of income growth and provision of information about mothers' access to health care services. Soc Sci Med. 71(11): 1973-80. 
[21]. Ruel MT, Levin CE, Armar-Klemesu M, Maxwell D, Morris SS, 1999. Good care practices can mitigate the negative effects of poverty and low maternal schooling on children's nutritional status: evidence from Accra. World Devel. 27(11): 1993-2009.

[22]. OMS/UNICEF, 2009. Normes de croissance OMS et identification de la malnutrition aiguë sévère chez l'enfant Déclaration commune. Genève: 2009

[23]. Prudhon C, Prinzo ZW, Briend A, Daelmans BM, Mason JB, 2006. Proceedings of the WHO, UNICEF and SCN Informal Consultation on Community-Based Management of Severe Malnutrition in Children. Food Nutr Bull. 27(3): 99-104.

[24]. OMS, 2000. La prise en charge de la malnutrition sévère : Manuel à l'usage des médecins et autres personnels de santé à des postes d'encadrement.p72

[25]. Mukalay WMA, Kalenga MKP, Dramaix M, Hennart P, Schirvel C, Kabamba LM, Kabyla IB, Donnen P, 2010. Facteurs prédictifs de la malnutrition chez les enfants âgés de moins de cinq ans à Lubumbashi (RDC). Santé Publique. 5(22) : 541-550

[26]. Bitwe R, Dramaix M, Hennart P, 2006. Modèle pronostique simplifié d'évaluation de la mortalité intrahospitalière globale des enfants en Afrique centrale. Tropical Medecin and international health. 2(1): 73-80.

[27]. Trehan I, Amthor ER, Maleta K, Manary JM, 2010. Evaluation of the routine use of amoxicillin as part of the home-based treatment of severe acute malnutrition. Tropical Medicine and International Health; 15(9): 1022-1028.

[28]. Berkley AJ, M.D., Lowe SB, Mwangi I, Williams T, Bauni E, Mwarumba S, Ngetsa C, Slack PEM, Njenga S, Hart AC, Maitland K, English M, Marsh K, Anthony GJ, 2006. Bacteremia among children admitted to a rural hospital in Kenya. The new england journal of medicine. 352(1): 39-47.

[29]. Kambale MR, Kasengi BJ, Kivukuto MJ, Cubaka ML, Mungo MB, Balaluka BG, 2016. Profil infectieux et mortalité des enfants âgés de 0 à 5 ans admis pour malnutrition aiguë sévère: étude de cohorte rétrospective au Centre Nutritionnel et Thérapeutique de Bukavu, République Démocratique du Congo. Pan Afr Med J. 23: 139. doi:10.11604/pamj.2016.23.139.8370

[30]. Linneman Z, Matilsky D, Ndekha MD, Manary JM, Maleta K, Manary JM, 2007. A largescale operational study of home-based therapy with ready-to-use therapeutic food in childhood malnutrition in Malawi. Maternal \& Child Nutrition 3, 206-215. doi.org/10.1111/j.1740-8709.2007.00095.x

[31]. Hossain IM, Dodd SN, Ahmed T, MiahMG, Jamil MK, NaharB, Alam B, Mahmood CB, 2009. Experience in Managing Severe Malnutrition in a Government Tertiary Treatment Facility in Bangladesh. J Health Popul Nutr. 27(1): 72-79. 